\title{
Hydrodynamic Voltammetry with the Convection Electrode. II. Experimental Verification for the Equation of the Limiting Current at the Convection Electrode
}

\author{
By \\ Junsuke Suzuki \\ (Faculty of Education, Shizuoka University, Oiwa, Shizuoka, Japan)
}

(Received Jan. 27, 1969)

\section{Summary}

An equation for the diffusional flux in the laminar flow at the plate electrode, in which the electrode reaction takes place only on a portion of the surface of the plate, was derived theoretically on the basis of the hydrodynamic conceptions developed by Levich.

Applying the theoretical treatment of Levich to the platinum plate convection electrode (PPCE), the equation of the limiting current is obtained as follows :

$$
i_{l}=0.428 \mathrm{nFAc}_{0} D^{2 / 3} v^{1 / 2} \nu^{-1 / 6} a^{-1 / 2}\left\{\left(1+\frac{x_{1}}{a}\right)^{3 / 4}-\left(\frac{x_{1}}{a}\right)^{3 / 4}\right\}^{2 / 3}
$$

In the case that $a / x_{1} \ll 1$, the limiting current is given by

$$
i_{l}=0.355 \mathrm{nFAc}_{0} D^{2 / 3} v^{1 / 2} \nu^{-1 / 6} a^{-1 / 3} \varkappa_{1}^{-1 / 6}
$$

Using a $2 \times 10^{-4} M$ hexacyanoferrate (II) solution, the experimental confirmation for the theoretical equation mentioned above was carried out. The results indicated that the limiting current at PPGE obeyed the equation. This shows that the velocity of the fluid flow is proportional to the tangential velocity of the rotating disk, that is, the value of the proportional constant is 0.40 , which is the same value obtained in the previous work.

\section{Introduction}

In the hydrodynamic voltammetry, the mass transport of the electroactive substances is caused principally by convective diffusion. The procedures for the forced convection, in general, are classified into two types; (1) moving electrode system, ${ }^{1111}$ and (2) moving solution system. ${ }^{12 \sim 25)}$ The procedure used in this study belongs to the latter.

In the ordinary voltammetry, the theory for the mass transport of electroactive substances to the electrode surface has been based on the conception of the Nernst's diffusion layer. In a rigorous treatment for the convective mass transport is a more extensive theory desired, that is, the mechanism of the convective mass transport should be discussed with the hydrodynamic theory.

In accordance with the hydrodynamic theory, the equations of the limiting current at the disk electrode and others in laminar flow were recently proposed by Matsuda ${ }^{2628)}$ and they were confirmed experimentally.

In the case of the so-called "convection electrode" in our studies, ${ }^{15) 20221) 24) 25)}$ it is very difficult to measure the velocity of laminar flow past the electrode. By using the treat- 
ment of Matsuda and assuming that the velocity of laminar flow past the electrode is proportional to the tangential velocity of the rotating disk as the stirrer, the proportional constant between the velocity of the flow and that of the rotating disk was calculated and it was found to be $0.40^{25}$.

The present investigation is concerned with the confirmation of the value of the proportional constant obtained in the previous study, ${ }^{25)}$ using the convection electrode of the other shape.

\section{The Treatment of the Data}

The general equation for convective mass transport in a laminar boundary layer over the plate electrode surface is given as follows:

$$
v \frac{\partial c}{\partial x}+u \frac{\partial c}{\partial y}=D \frac{\partial^{2} c}{\partial y^{2}}
$$

where $v$ and $u$, which are determined from both equations of Navier-Stockes and of continuity, are the components of the velocity of the solution parallel to the axes $x$ and $y$ (see Fig. 1), respectively, $D$ the diffusion coefficient of electroactive substance and $c$ its concentration.

In order to evaluate the concentration distribution and the flux at the present platinum plate convection electrode (PPCE), equation (1) must be solved with the following boundary conditions:

$$
\begin{array}{ll}
\frac{\partial c}{\partial y}=0 & \text { for } x<x_{1} y=0 \\
c=0 & \text { for } x>x_{1} y=0 \\
c=c_{0} & \text { as } y \rightarrow \infty \\
c=c_{0} & \text { at } x=0 \quad y=0
\end{array}
$$

The complete solution for equation (1) satisfying the boundary conditions (2) to (5) is given by Levich ${ }^{29}$

$$
c(x, y)= \begin{cases}c_{0} & \text { for } x<x_{1} \\ \left.\frac{c_{0}}{\Gamma\left(\frac{1}{3}\right)}\right|_{0} ^{\frac{1}{12} \cdot \frac{y^{3}}{x^{3 / 2}} \cdot \frac{1}{1-\left(x_{1} / x\right)^{3 / 4}} \cdot \frac{\beta^{2}}{2 D^{3}}} \\ \exp (-t) t^{-2 / 3} d t & \text { for } x>x_{1}\end{cases}
$$

where

$$
\beta=\frac{D\left(\frac{\alpha}{2}\right)^{1 / 2} v_{0}^{3 / 4}}{\nu^{1 / 4}}
$$

and $\alpha$ is $1.33, \nu$ the kinematic viscosity of the solution, $v_{0}$ the velocity at the outer edge of the boundary layer, and $c_{0}$ bulk concentration.

The flux for $x>x_{1}$ may be obtained by differentiating equation (6) with respect to $y$ and putting $y \rightarrow 0$, that is,

$$
D\left(\frac{\partial c}{\partial y}\right)_{y=0}=\frac{3}{12^{1 / 3}} \cdot \frac{c_{0}}{2^{1 / 3} \Gamma\left(\frac{1}{3}\right)} \cdot \frac{1}{x^{1 / 2}} \cdot \frac{\beta^{2 / 3}}{\left\{1-\left(x_{1} / x\right)^{3 / 4}\right\}^{1 / 3}}
$$

where $\boldsymbol{T}$ is gamma function.

The limiting current $i_{l}$ at PPCE, therefore, follows equation (8). 


$$
i_{l}=0.677 \mathrm{nFA} c_{0} D^{2 / 3} v_{0}^{1 / 2} \nu^{-1 / 6} a^{-1 / 2}\left\{\left(1+\frac{x_{1}}{a}\right)^{3 / 4}-\left(\frac{x_{1}}{a}\right)^{3 / 4}\right\}^{2 / 3}
$$

If $a / x_{1} \ll 1$ is, we can show that

$$
i_{l}=0.559 \mathrm{nFA} c_{0} D^{2 / 3} v_{0}^{1 / 2} \nu^{-1 / 6} a^{-1 / 3} x_{1}^{-1 / 6}
$$

where $A$ and $a$ are the area and the diameter of the working surface of the electrode, respectively, and $n$ and $F$ the ordinary signature.

\section{Experimental}

Apparatus. - The Yanagimoto Polarograph Type PA 102 was used to record a currentvoltage curve. The rotating system and the electrolytic cell used were the same as had been described in the previous paper. ${ }^{25}$ PPGE was constructed as shown in Fig. 1.

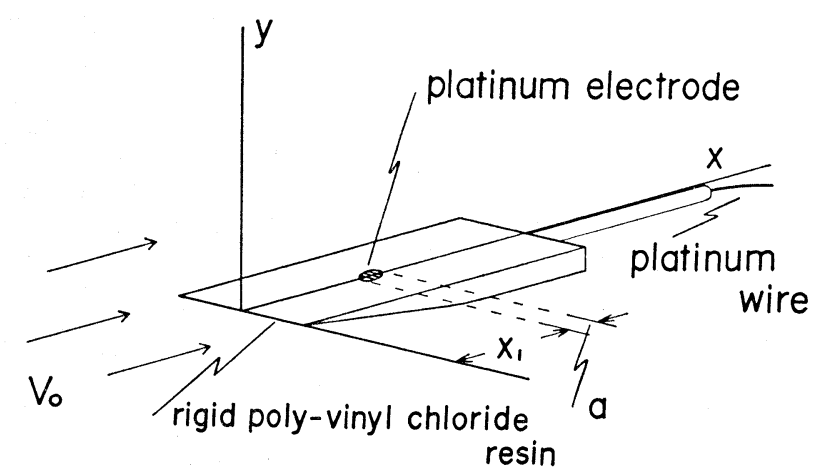

Fig. 1. Coordinate system and platinum plate convection electrode

The size of plate $: 0.5 \mathrm{~cm}$ in width, $0.3 \mathrm{~cm}$ in thickness and $2.0 \mathrm{~cm}$

in length

Reagents.-All the chemicals used were of reagent grade, extra pure and all solutions were prepared from redistilled water. Only a ferrocyanide solution was freshly prepared daily.

Pre-treatment of PPCE.-The pre-treatment for PPGE is very important to obtain a reproducible current-voltage curve. It was the same as had been described in the previous paper, ${ }^{25}$ that is, by polishing lightly the working surface of the electrode with fine carborundum abrasives before use.

Procedure.-The electrode was set to the electrolysis cell, and about $30 \mathrm{~m} l$ of the electrolyte solutions were poured into it. All the electrolyte solutions were deaerated, prior to and during use, with purified nitrogen gas, while rotating the disk.

In all experiments, a saturated calomel electrode was used as reference electrode and the temperature of the cell was kept at $25 \pm 0.1^{\circ} \mathrm{C}$.

\section{Results and Discussion}

Reproducibility of the limiting current.

The limiting current depends upon the pre-treatment of the electrode surface. In the previous paper, $\left.{ }^{25}\right)$ the reproducibility of the current-voltage curve for reduction of hexacyanoferrate (III) ions or oxidation of hexacyanoferrate (II) ions has been investigated by the procedure of the pre-treatment as mentioned above and the satisfactory 
results were obtained.

Similarly, in the present work the reproducibility of the limiting current was investigated by using the same procedure of the pre-treatment. The results are summarized in Table I.

Table I. Reproducibility of the limiting current $(\mu \mathrm{A})$.

\begin{tabular}{c|c|c|c|c|c|c|c}
\hline Exp. No. & 1 & 2 & 3 & 4 & 5 & 6 & 7 \\
\hline$i_{l}$ & 3.40 & 3.50 & 3.40 & 3.55 & 3.46 & 3.40 & 3.50 \\
\hline
\end{tabular}

Tangential velocity of the rotating disk $: 115.4 \mathrm{~cm} / \mathrm{sec}$

Concentration of hexacyanoferrate (II) $: 2 \times 10^{-4} M$ in $1 M \mathrm{KCl}$

Area of electrode surface : $0.0314 \mathrm{~cm}^{2}$

It can be seen from the table that a good reproducibility is obtained.

Fluid flow past the PPCE.

The limiting current should obey equation (9), when the fluid flow past PPCE is laminar and steady. Whether the fluid flow past the electrode surface is laminar or not, it depends upon the value of the Reynolds number $(R e)$. The dimensionless parameter $R e$ is given by

$$
R e=v_{0} \cdot l / \nu
$$

where $l$ is the length of the plate.

In general, the value of the parameter $R e$, at which the flow past the plate is laminar, is smaller than $5 \times 10^{5} .^{30}$ )

On the other hand, as mentioned in the previous paper, $\left.{ }^{25}\right)$ the flow rate past the convection electrode is given as follows;

$$
v_{0}=0.40 \cdot v
$$

where $v(=3 \pi \mathrm{R})$ is the tangential velocity of the rotating disk in $\mathrm{cm} / \mathrm{sec}$ ( $\mathrm{R}$ the revolution numbers of the rotating disk per second). Therefore, the critical value of the flow rate, below which the fluid flow past PPCE is laminar, is given by

$$
v_{\text {crit }}=5 \times 10^{5} \cdot \nu / l
$$

In the present work, the kinematic viscosity of solution is $0.863 \times 10^{-2} \mathrm{~cm}^{2} / \mathrm{sec}$ at $25^{\circ} \mathrm{C}$ and the length of the plate of the present electrode is $2.0 \mathrm{~cm}$. Hence, the critical value of the flow rate is about $2 \times 10^{3} \mathrm{~cm} / \mathrm{sec}$. This corresponds to about $5000 \mathrm{~cm} / \mathrm{sec}$ of the tangential velocity of the rotating disk. Therefore, it is considered that the flow past PPCE is laminar, because the flow rates in the present investigation are always comprised within this range.

Effects of the tangential velocity of the rotating disk on the limiting current.

Dependence of the limiting current upon the tangential velocity of the rotating disk was investigated in the range from 115.4 to $230.8 \mathrm{~cm} / \mathrm{sec}$, by using a $2 \times 10^{-4} M$ hexacyanoferrate (II) solution. The results are shown in Table II.

The table shows the gradual increase in the limiting current with increasing velocity of the rotating disk.

From the data of the second column in the table, relation between the limiting current and the square root of the tangential velocity of the rotating disk is obtained, as shown in the sixth column of Table II. The column shows to be a linear relationship between $i_{l}$ and $v .^{1 / 2}$ Namely, this indicates that the flow past PPCE is the laminar ${ }^{27)}$ and the limiting current obeys equation(9). 
Table II. Relation between the limiting current, $i_{l}$, and the tangential velocity of the rotating disk, $v$. The concentration of hexacyanoferrate (II) was $2 \times 10^{-4} M$ in $1 M \mathrm{KCl}$, and the values of $x_{1}, a$, and A were $1.0 \mathrm{~cm}, 0.2 \mathrm{~cm}$, and $0.0314 \mathrm{~cm}^{2}$, respectively.

\begin{tabular}{c|c|c|c|c|c}
\hline$v, \mathrm{~cm} / \mathrm{sec}$ & $i_{l}(\mathrm{obs}), \mu \mathrm{A}$ & $i_{l}(\mathrm{calc}), \mu \mathrm{A} *$ & Deviation, $\%$ & $v^{1 / 2}$ & $i_{l}(\mathrm{obs}) / v^{1 / 2}$ \\
\hline 115.4 & 3.46 & 3.42 & -1.17 & 10.7 & 0.32 \\
150.7 & 3.88 & 3.89 & +0.26 & 12.2 & 0.32 \\
188.4 & 4.45 & 4.34 & -2.54 & 13.7 & 0.32 \\
230.8 & 4.88 & 4.84 & -0.83 & 15.2 & 0.32 \\
\hline
\end{tabular}

* Calculated from equation (13), using the value of $D$ obtained by Stackelberg et al. ${ }^{31)}$

The theoretical limiting current at PPCE and its observed value.

A new equation of the limiting current is derived from equations (9) and (11), that is,

$$
i_{l}=0.355 \mathrm{nFA} c_{0} D^{2 / 3} v^{1 / 2} \nu^{-1 / 6} a^{-1 / 3} x_{1}^{-1 / 6}
$$

The comparisons of the experimental values of the limiting current and the theoretical values calculated from equation (13) are summarized in Table II. It can be seen from the table that the experimental data are in excellent agreement with the theoretical values calculated from equation (13).

\section{Acknowledgement}

The author wishes to express his thanks to Professor Tokuro Ozaki of Shizuoka University for his helpful discussion.

\section{References}

1) I.M. Kolthoff and H.A. Laitinen, J. Phys. Chem., 45, 1079 (1941).

2) J. Heyrovsky and J. Forejt, Z. physik. Chem., 193, 77 (1943).

3) T.S. Lee, J. Am. Chem. Soc., 74, 5001 (1952).

4) I.M. Kolthoff and J. Jordan, J. Am. Chem. Soc., 76, 3843 (1954).

5) Z. Galus, G. Olson, H.Y. Lee and R.N. Adams, Anal. Chem., 34, 164 (1962).

6) Z. Galus and R.N. Adams, J. Phys. Chem., 67, 866 (1963).

7) I. Fried and P.J. Elving, Anal. Chem., 37, 464(1965).

8) W.J. Albery, Trans. Faraday Soc., 62, 1915 (1966).

9) W.J. Albery and S. Bruckenstein, ibid., 62, 1920, 1946 (1966).

10) W.J. Albery, S. Bruckenstein, and D.T. Napp, ibid., 62, 1932 (1966).

11) W.J. Albery, S. Bruckenstein, and D.C. Johnson, ibid., 62, 1938 (1966).

12) O.H. Muller, J. Am. Chem. Soc., 69, 2992 (1947).

13) J. Jordan, Anal. Chem., 27, 1708 (1955).

14) J. Jordan, R.A. Javick and W.Z. Ranz, J. Am. Chem. Soc., 81, 3846 (1958).

15) T. Ozaki and T. Nakayama, Nippon Kagaku Zasshi, 81, 98 (1960).

16) A. Kimla, Collection Czech. Chem. Commun., 28, 2696 (1963).

17) F. Strafelda and A. Kimla, ibid., 28, 1515 (1963).

18) W.J. Blaedel, C.L. Olson and L.R. Sharma, Anal. Chem., 35, 2100 (1963).

19) J. C. Bazan and A.J. Arvia, Electrochim. Acta, 9, 17 (1964).

20) J. Suzuki and T. Ozaki, Bull. Chem. Soc. Japan, 37, 230, 789 (1964). 
21) J. Suzuki, ibid., 39. 1898 (1966).

22) W.J. Blaedel and L.N. Klatt, Anal. Chem., 38, 879 (1966).

23) L.N. Klatt and W.J. Blaedel, ibid., 39, 1065 (1967).

24) J. Suzuki, Bull, Chem. Soc. Japan, 40, 101 (1967).

25) J. Suzuki, Rev. Polarog. (Kyoto), 15, 21 (1968).

26) H. Matsuda, J. Electroanal. Chem., 15, 109 (1967).

27) P. Delahay, "New Instrumental Methods in Electrochemistry," Interscience, New York, 1954, p. 227.

28) H. Matsuda and Y. Yamada, The 18th Annual Meeting of the Chemical Society of Japan, Osaka (1962).

29) V.G. Levich, "Physicochemical Hydrodynamics, "Prentice-Hall, Inc., Englewood Gliffs, N.J., 1962, pp. 102-107.

30) Y. Harada, "Ryutai no Rikigaku" Makishoten, Tokyo, 1955, pp. 202-204.

31) M.v. Stackelberg, M. Pilgram and V. Toome, Z. Elektrochemie, 57, 342 (1953).

対流電極による流体力学的ボルタンメトリー（II）

対流電極に対する限界電流式の実験的確認

鈴 木 諒 亮

(静岡大学教育学部, 静岡市大岩)

流体力学的ボルタンメトリーにおいては，物質移動 は主として刘流によりおてなわれる。対流を起す方法 としては (a) 電極自身を動かす場合, (b) 溶液を攪拌器 または循環器などにより流動させる場合の 2 通りがあ る。本研究における対流平面板電極は, 後者に属し, Fig. 1 亿示したように平面板の一部を電極表面とし, 他の部分では電極反応が起きない状態にしたものであ る. ての平面板上での流れの状態は Reynolds number により知ることが出来るが，本実験条件のもとで は，首流であるととが知られた。層流々れに平行にお いた平面板上への物質移動を知るためには, 平面板上 での速度分布および濃動分布の両方を知らねばならな い. 本平面板上での濃度分布は Levich により与えら れた速度分布を考慮した対流拡散式を解くことにより 求められ(6)式で与えられる.

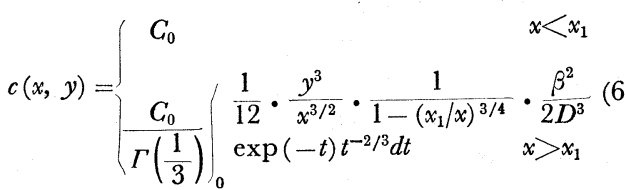

これより電極表面 $\mathrm{A}$ なる平面板対流電極における限界
電流は(8)式のようになる。

$$
\begin{aligned}
i_{l} & =0.677 n F A c_{0} D^{2 / 3} v_{0}{ }^{1 / 2} \nu^{-1 / 6} a^{-1 / 2}\left\{\left(1+\frac{x_{1}}{a}\right)^{3 / 4}\right. \\
& \left.-\left(\frac{x_{1}}{a}\right)^{3 / 4}\right\}^{2 / 3}
\end{aligned}
$$

また， $a / x_{1} \ll 1$ なる場合には (8)式は簡単になり， (9)式が与えられる（本対流電極は，乙の場合に相当す る).

$$
i_{l}=0.559 n F A c_{0} D^{2 / 3} v_{0}^{1 / 2} \nu^{-1 / 6} a^{-1 / 3} x_{1}^{-1 / 6}
$$

流速 $v_{0}$ と回転円板線速度 $v$ との間には, (11)式に示す 関係があり.

$$
v_{0}=0.40 v
$$

したがって，限界電流式は

$$
i_{l}=0.355 n F A c_{0} D^{2 / 3} v^{1 / 2} \nu^{-1 / 6} a^{-1 / 3} x_{1}^{-1 / 6}
$$

となる。

$1 M \mathrm{KCl}$ 中の $2 \times 10^{-4} M \mathrm{Fe}(\mathrm{GN})_{6}{ }^{4-}$ 溶液を用いて 理論值および実測值の比較をしたとてろ，きわめてよ く一致した結果が得られた（Table II)。乙れは前報 で実験的に求めた(11)式の関係が, 対流電極一般にあて はまるととを示すものである。 